\title{
Determinan impor Indonesia
}

\author{
Andi Andini Adhalia*; Rachmad R; Rahma Nurjanah \\ Prodi Ekonomi Pembangunan Fak.Ekonomi dan Bisnis Universitas Jambi \\ *E-mail korespondensi: andiandiniadhalia18@gmail.com
}

\begin{abstract}
The purpose of this study is to analyze: 1) The development of import values, inflation, exchange rates, FDI, and Indonesia's foreign exchange reserves for the period 19962017. 2) The influence of Indonesia's import determinants for the 1996-2017 period. In this study, the type of data used is secondary data based on the period 1996-2017. The method used in this research is descriptive analysis and quantitative analysis, namely multiple regression analysis. The results of this study indicate: 1) The average development of imports is $8.68 \%$ per year, the average inflation is $10.30 \%$ per year, the average development of the rupiah exchange rate against the dollar is $11.17 \%$ per year, the average development FDI is $5.66 \%$ per year, and the average development of foreign exchange reserves is $11.83 \%$ per year. 2) Simultaneously or together inflation, exchange rate, FDI, and foreign exchange reserves have a positive and significant impact on Indonesian imports. Partially, inflation has a positive and significant effect on Indonesian imports, the exchange rate has a negative and significant effect on Indonesian imports, FDI has a positive but not significant effect on Indonesian imports, and foreign exchange reserves have a positive and significant effect on Indonesian imports.
\end{abstract}

Keywords: Imports, Inflation, Exchange rates, Foreign direct investment, Foreign exchange reserves

\begin{abstract}
Abstrak
Tujuan penelitian ini untuk menganalisis: 1) Perkembangan nilai impor, inflasi, kurs, PMA dan cadangan devisa Indonesia periode 1996-2017. 2) Pengaruh determinan impor Indonesia periode 1996-2017. Dalam penelitian ini jenis data yang digunakan adalah data sekunder berdasarkan kurun waktu periode 1996-2017. Metode yang digunakan dalam penelitian ini adalah analisis deskriptif dan analisis kuantitatif yaitu analisis regresi berganda. Hasil penelitian ini menunjukkan: 1) Rata-rata perkembangan impor sebesar $8,68 \%$ pertahun, rata-rata inflasi sebesar $10,30 \%$ pertahun, rata-rata perkembangan nilai tukar rupiah terhadap dollar sebesar $11,17 \%$ pertahun, rata-rata perkembangan PMA sebesar 5,66\% pertahun, dan rata-rata perkembangan cadangan devisa sebesar $11,83 \%$ pertahun. 2) Secara simultan atau bersama-sama inflasi, kurs, PMA dan cadangan devisa berpengaruh positif dan signifikan terhadap impor Indonesia. Secara parsial inflasi berpengaruh positif dan signifikan terhadap impor Indonesia, kurs berpengaruh negatif dan signifikan terhadap impor Indonesia, PMA berpengaruh positif tetapi tidak signifikan terhadap impor Indonesia, dan cadangan devisa berpengaruh positif dan signifikan terhadap impor Indonesia.
\end{abstract}

Kata kunci: Impor, Inflasi, Kurs, Penanaman modal asing, Cadangan devisa

\section{PENDAHULUAN}

Perdagangan internasional berperan penting untuk memenuhi kebutuhan negara di dunia. Dengan perdagangan internasional, perekonomian akan saling terjalin dan tercipta suatu hubungan ekonomi yang saling mempengaruhi suatu negara dengan 
negara lain serta lalu lintas barang dan jasa akan membentuk perdagangan antar bangsa. Perdagangan internasional merupakan kegiatan yang bertujuan untuk meningkatkan kesejahteraan masyarakat suatu negara. Terjadinya perekonomian dalam negeri dan luar negari akan menciptakan suatu hubungan yang saling mempengaruhi antara satu negara dengan negara lainnya, salah satunya adalah berupa pertukaran barang dan jasa antarnegara.

Impor terjadi karena kurangnya produksi dalam negeri sehingga menyebabkan negara harus membeli barang atau jasa dari negara lain. Dalam proses pembelian barang atau jasa tersebut yang digunakan sebagai alat pembayaran adalah valuta asing yang berasal dari cadangan devisa. Hubungan impor dengan cadangan devisa adalah ketersediaan devisa sangat mempengaruhi keberlangsungan kegiatan impor, mengingat kegiatan impor dilakukan untuk memenuhi kebutuhan dalam negeri akibat dari keterbatasan produksi dalam negeri. Terhambatnya kegiatan impor akan berdampak juga pada terhambatnya kegiatan dalam negeri. (Juniantara, 2012). Variabel yang mempengaruhi impor suatu negara yakni tingkat inflasi. Inflasi menyebabkan harga barang impor menjadi lebih murah daripada barang yang dihasilkan dalam negeri. (Sukirno, 2016). Apabila harga barang naik secara terus menerus juga akan mempengaruhi permintaan terhadap impor.

Inflasi dapat disebabkan oleh adanya kenaikan dalam jumlah permintaan (demand pull inflation) ataupun penurunan dalam jumlah penawaran (cost push inflation). Demand pull inflation terjadi apabila perusahaan atau penyedia tidak mampu dengan cepat melayani permintaan masyarakat dalam pasaran dan biasanya terjadi pada saat perekonomian mencapai tingkat penggunaan tenaga kerja penuh dan pertumbuhan ekonomi berjalan dengan pesat. Sedangkan cost push inflation merupakan masalah kenaikan harga-harga dalam perekonomian yang diakibatkan oleh kenaikan biaya produksi dan biasanya terjadi ketika perekonomian mengalami kekurangan tenaga kerja. Kenaikan harga atau inflasi tersebut menyebabkan barang-barang negara itu tidak dapat bersaing dipasaran internasional (Sukirno, 2006).

Impor suatu negara juga di pengaruhi dengan yaitu nilai tukar yang merupakan harga atau nilai mata uang suatu negara yang dinyatakan dalam nilai mata uang negara lain. Bila kurs suatu negara mengalami depresiasi maka impornya akan menurun sedangkan bila kursnya mengalami apresiasi maka impornya akan meningkat. Oleh karena itu, perkembangan kurs mata uang dalam negeri terhadap mata uang asing khusunya dollar AS menjadi penting untuk diamati mengingat dollar AS merupakan mata uang internasional. Sebagai negara berkembang, Indonesia merupakan tujuan dari kegiatan investasi asing yang sangat potensial. Penanaman modal asing bagi Indonesia berperan sebagai elemen utama perkembangan industri dan pertumbuhan ekonomi. Perdagangan internasional dan penanaman modal asing dianggap sumber transfer pengetahuan dan teknologi, terutama dari negara industri ke negara sedang berkembang, termasuk Indonesia. Penanaman modal asing adalah sebagai investasi aset dari luar negeri yang memasuki struktur, peralatan dan organisasi dalam negeri. Masuknya modal asing ke dalam negeri dipercaya dapat meningkatkan impor.

Analisis tentang sektor perdagangan luar negeri Indonesia selama ini terlalu didominasi oleh analisis tentang ekspor. Di satu sisi hal ini dapat dipahami karena ekspor merupakan satu-satunya andalan penghasil devisa yang berasal dari kekuatan sendiri, sehingga negara berkembang berkepentingan untuk menguasai pengetahuan tentang penghasil devisanya ini. Peran devisa ini sangat penting, terutama untuk negara berkembang seperti Indonesia. Devisa dibutuhkan untuk membayar impor, jaminan 
pembayaran impor tiga bulan mendatang, membayar utang luar negeri dan bunganya, dan mendukung stabilitas nilai rupiah.

\section{METODE}

Metode yang digunakan dalam penelitian ini adalah metode deskriptif dan kuantitatif. Data yang digunakan dalam penelitian ini adalah data sekunder yang diperoleh dari BPS, BI dan Kemendag RI. Alat analisis yang digunakan yaitu regresi linear berganda. Model persamaannya adalah sebagai berikut (Amri, 2000)

\section{$\operatorname{LogMt}=\beta_{0}+\beta_{1} I N F t+\beta_{2} \operatorname{LogKURS} S_{t}+\beta_{3} \operatorname{LogPMA} A_{t}+\beta_{4} \operatorname{LogDEV} t+e_{t}$}

Dimana:

$\log _{\mathrm{t}} \quad=$ Nilai impor Indonesia (juta US\$)

$\mathrm{INF}_{\mathrm{t}} \quad=$ Inflasi $(\%)$

LogKURS $_{\mathrm{t}} \quad=$ Kurs/ nilai tukar Rupiah terhadap Dollar AS (Rp/US\$)

LogPMA $_{t} \quad=$ Nilai PMA Indonesia (juta US\$)

$\operatorname{LogDEV}_{\mathrm{t}} \quad=$ Nilai cadangan devisa Indonesia (juta US\$)

$\beta_{0} \quad=$ Konstanta

$\beta_{1-4} \quad=$ Koefisien elastisitas

$\mathrm{e}_{\mathrm{t}} \quad=$ Error term

\section{HASIL PENELITIAN DAN PEMBAHASAN}

Perkembangan impor, inflasi, kurs, PMA dan cadangan devisa dari tahun ke tahun terus berfluktuasi. Gejala naik turunnya disebabkan oleh berbagai faktor yang memiliki keterkaitan terhadap impor, inflasi, kurs, PMA dan cadangan devisa.

\section{Perkembangan impor Indonesia}

Perkembangan impor Indonesia periode 1996-2017 berfluktuatif setiap tahunnya. Perkembangan tertinggi yaitu pada tahun 2008 yaitu naik sebesar 73,48\%. Dan tertinggi kedua sebesar $42,93 \%$ pada tahun 2004 . Hal ini di dorong oleh impor migas dan non migas yang masing-masing naik sebesar $24,5 \%$ dan 39,4\%. Dengan defisit jasa-jasa (termasuk income dan current transfer), surplus neraca transaksi berjalan pada tahun 2008. Investasi langsung asing yang juga mencapai surplus. Hal ini terutama dipengaruhi oleh arus modal keluar dari para investor guna memenuhi kebutuhan konsolidasi keuangan global yang berimbas pada pelepasan Surat Utang Negara (SUN) dan Surat Berharga Bank Indonesia (SBI). Realisasi APBN tahun 2008 banyak dipengaruhi oleh perkembangan ekonomi global, antaralain tingginya harga komoditi khususnya minyak bumi dan gas alam (migas) serta depresiasi nilai tukar Rupiah terhadap uang US Dollar. Dari tahun ke tahun nilai impor Indonesia mengalami peningkatan tetapi ada juga pada tahun tertentu mengalami penurunan. Nilai impor turun ekstrim pada tahun 1998 sebesar -34,41\%. Dan pada tahun 2009 sebesar -25,05\%. Hal ini disebabkan oleh melemahnya peran investasi swasta dan ekspor akibat turunnya perekonomian global dan akibat krisis ekonomi. Dengan perekonomian Indonesia yang tidak stabil, mengakibatkan cadangan devisa yang sedikit. Rata-rata perkembangan impor sebesar $8,68 \%$ pertahun. Perkembangan impor Indonesia dapat dilihat pada Grafik 1. 


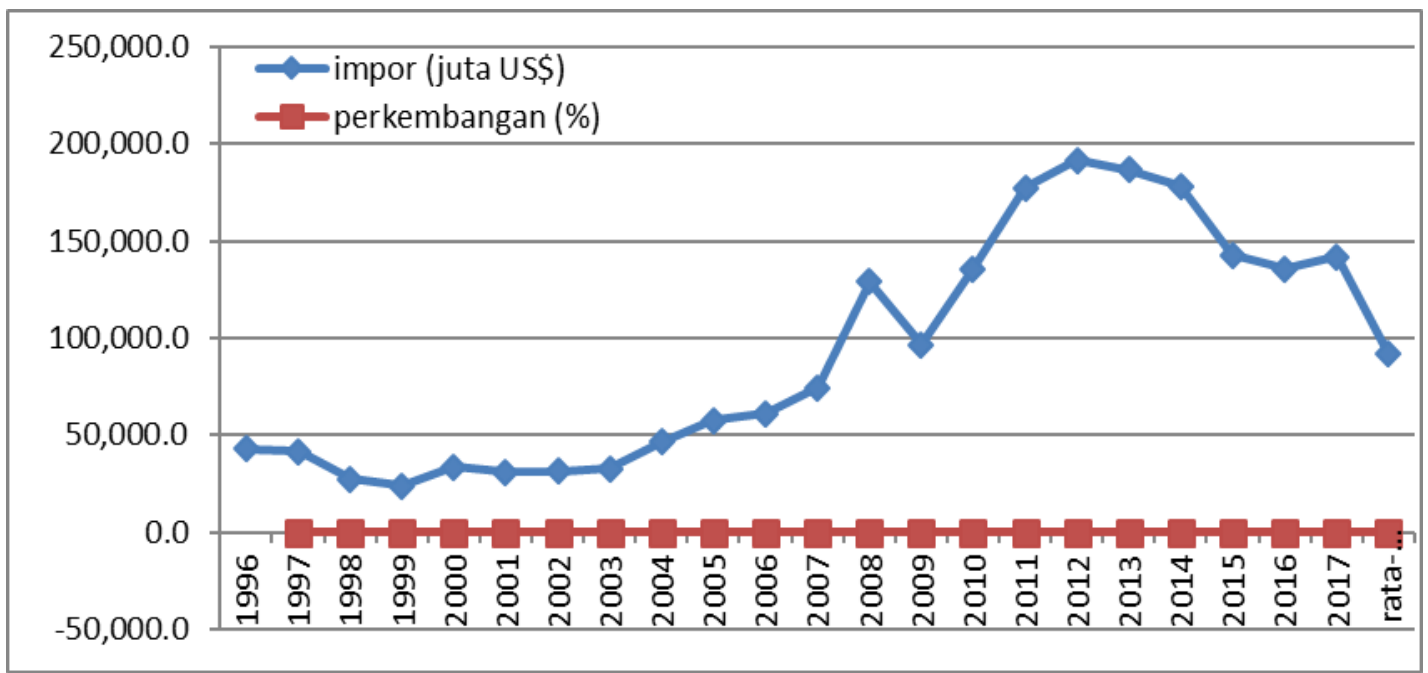

Grafik 1. Perkembangan impor Indonesia Periode 1996-2017

Sumber: Data diolah, 2018

\section{Perkembangan inflasi Indonesia}

Kebijakan yang diambil oleh pemerintah berguna untuk memonitor perkembangan inflasi Indonesia. Jika pemerintah tidak mampu untuk memonitor inflasi ini akan berakibat pada ketimpangan perekonomian. Harga akan semakin meningkat dan apabila terus berlanjut akan berdampak krisis moneter. Perkembangan inflasi indonesia dapat dilihat pada Grafik 2berikut:

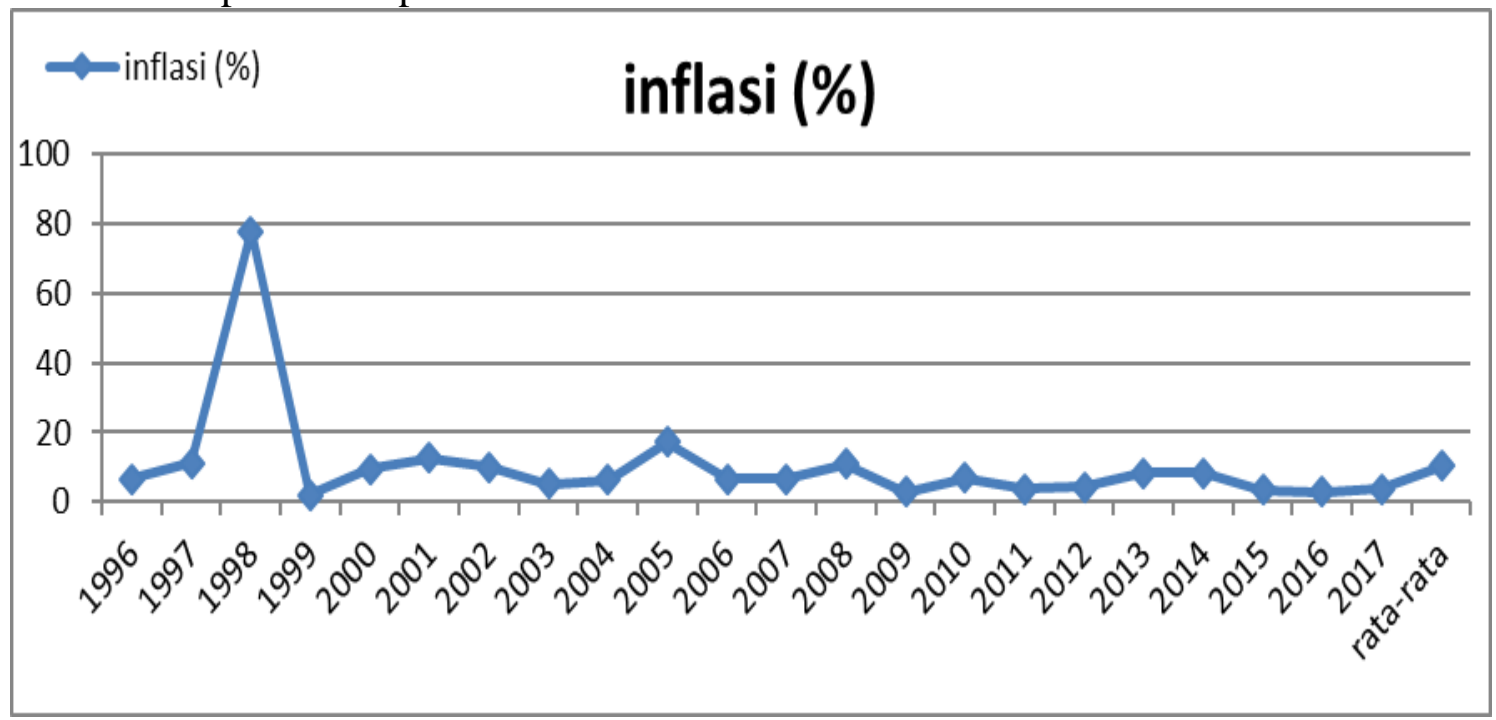

Grafik 2. Pekembangan inflasi Indonesia Periode 1996-2017

Sumber: Data diolah,2018

Grafik 2 diketahui bahwa perkembangan inflasi dari tahun ke tahun mengalami fluktuasi. Dengan perkembangan inflasi tertinggi pada tahun 1998 sebesar 77,6\% dikarenakan terjadinya krisis moneter yang terjadi pada tahun tersebut. Perkembangan inflasi terendah terjadi pada tahun 1999 secara signifikan turun sebesar 2\% hal ini dikarenakan pasca krisis moneter pada tahun 1998. Dan pada tahun 2009 sebesar $2,78 \%$. Hal ini dikarenakan menguatnya nilai tukar rupiah dan juga dipengaruhi oleh membaiknya ekspektasi inflasi karena harapan membaiknya kondisi ekonomi dan juga tersedianya pasokan kebutuhan pokok masyarakat khususnya beras melalui pasar bebas yang dilakukan Bulog. Dan rata-rata inflasi Indonesia adalah sebesar 10,3\% pertahun. 


\section{Perkembangan nilai tukar rupiah terhadap dollar}

Nilai tukar mempunyai peranan penting dalam kegiatan perdagangan internasional seperti kegiatan ekspor dan impor. Faktor yang penting pula untuk membantu kelancaran perdagangan internasional. Perkembangan nilai tukar dari waktu ke waktu akan terus berfluktuasi mengikuti permintaan dan penawaran mata uang asing. perkembangan kurs tertinggi terjadi pada tahun 1997- 1998 berturut-turut sebesar 95,13\% dan 72,58\% dengan nilai kurs sebesar 4.650 Rp/US\$ menjadi 8.025 Rp/US\$. Hal ini dikarenakan krisis ekonomi Indonesia dan terjadi pelemahan rupiah yang sangat drastis. Sebagaimana dapat dilihat pada grafik dibawah ini:

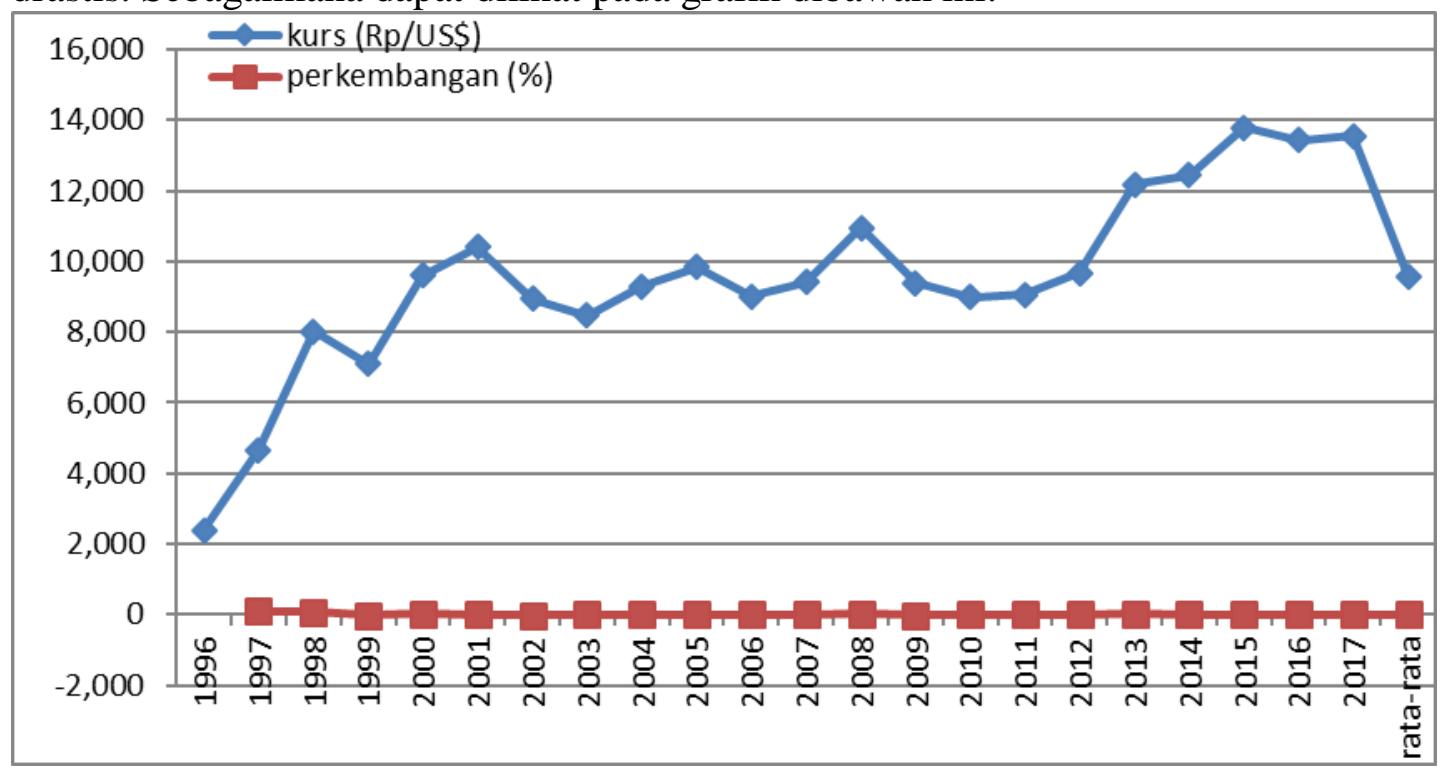

Grafik 3. Perkembangan kurs Indonesia Periode 1996-2017

Sumber: Data diolah, 2018

Perkembangan terendah pada tahun 2009 sebesar $-14,16 \%$ dan terendah kedua pada tahun 2002 sebesar -14,04\%. Hal ini dikarenakan pertumbuhan ekonomi Indonesia pada tahun 2009 yang membuat kurs kembali terapresiasi, yang pada tahun sebelumnya kurs depresiasi akibat masa krisis finansial global di Amerika Serikat. Rata-rata perkembangan kurs Indonesia sebesar $11,17 \%$ pertahun.

\section{Perkembangan penanaman modal asing Indonesia}

Untuk menunjang perkembangan ekonomi Indonesia, pemerintah saat ini sedang berupaya untuk menarik lebih banyak minat investor asing untk menanam modal di Indonesia. Masuknya PMA dapat membantu meningkatkan pembangunan ekonomi dalam hal pembangunan modal dan menciptakan lapangan pekerjaan. Penanaman modal asing di Indonesia mengalami fluktuasi. Perkembangan tertinggi terjadi pada tahun 2007 naik sebesar 73,02\% dan tertinggi kedua pada tahun 2010 sebesar 49,92\%. Hal ini dikarenakan masuknya investasi asing langsung ke sektor non migas.

Semakin meningkatnya PMA disebabkan oleh upaya yang dilakukan pemerintah untuk menciptakan iklim investasi di Indonesia yang kondusif, karena timbul kecenderungan pada investor hanya mau menanamkan modalnya di tempat yang paling menguntungkan. Kebijakan dalam negeri dalam menarik investor bisa dilihat dari terbentuknya kekuatan industri penunjang dan industri hulu akan menciptakan industrialisasi yang tangguh untuk menghadapi persaingan global. Perkembangan terendah terjadi pada tahun 1998 turun sebesar $-59,85 \%$ dan terendah kedua pada tahun 2002 sebesar -34,98\%. Hal ini dikarenakan pada tahun 1998 perekonomian Indonesia sangat tidak stabil, menyebabkan investor asing tidak ingin menanamkan modalnya di 
Indonesia. Dapat dilihat dari Grafik 4 dibawah ini yang menunjukkan perkembangan PMA.

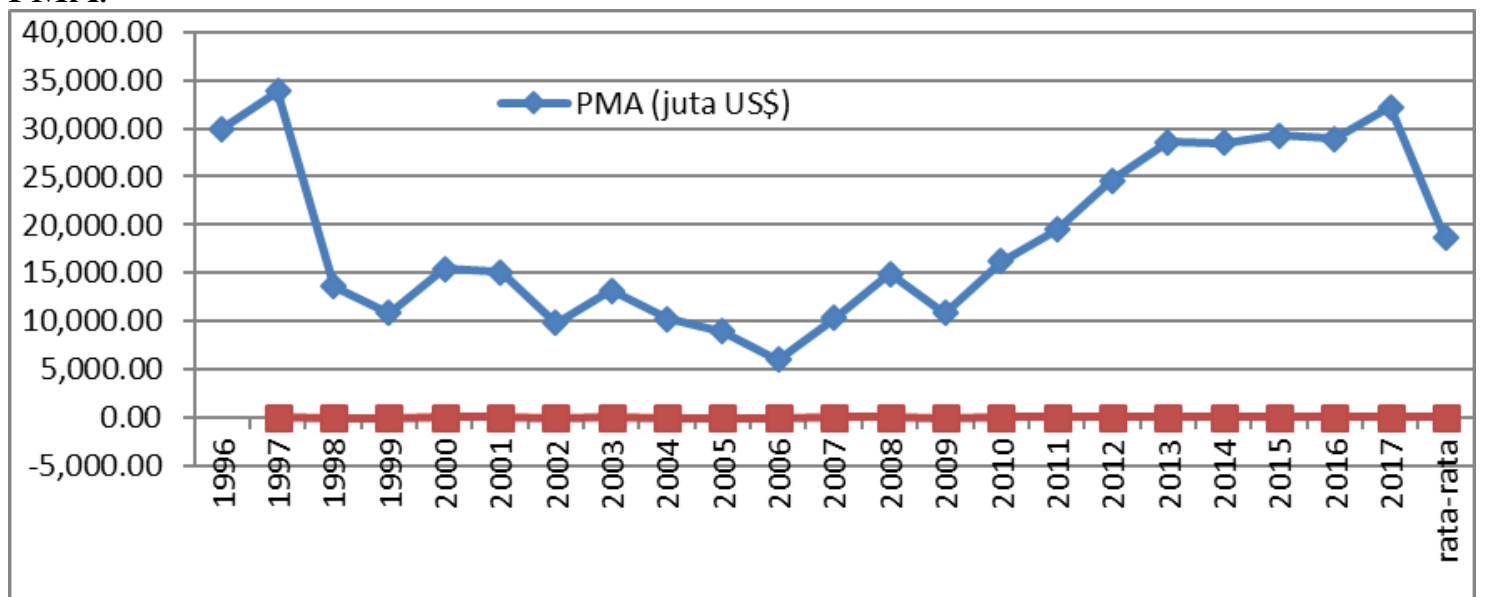

Grafik 4. Perkembangan PMA Indonesia periode 1996-2017

Sumber: Data diolah, 2018

Grafik 4 dapat dilihat juga penurunan PMA dikarenakan adanya faktor-faktor yang menghambat masuknya investasi asing atau PMA di Indonesia diantaranya faktor uncertainly (ketidakjelasan) yang diciptakan oleh pemerintah sebagai penjamin keamanan dan penentu keuntungan para investor asing di Indonesia. Disebabkan juga karena perlambatan perekonomian dunia dan domestik, selain itu ketidakpastian pasar keuangan global yang meningkat. Rata-rata perkembangan PMA Indonesia sebesar $5,66 \%$ setiap tahunnya.

\section{Perkembangan cadangan devisa Indonesia}

Diketahui dari tahun ketahun cadangan devisa Indonesia mengalami fluktuatif. Krisis yang dialami Indonesia pada tahun 1998 ternyata tidak berdampak terhadap cadangan devisa bahkan cenderung meningkat sampai tahun 2000. Fenomena tersebut dikarenakan cadangan devisa Indonesia tidak lagi hanya diperoleh dari surplus ekspor, tetapi berasal dari pinjaman luar negeri yang dipergunakan untuk menutupi defisit neraca pembayaran. Perkembangan nilai cadangan devisa tertinggi pada tahun 2010 sebesar 45,54\% dan 2007 sebesar 33,66\%. Hal ini dikarenakan arus modal yang masuk melalui SBI, pasar modal dan SUN positif bagi kecukupan cadangan devisa. Kenaikan cadangan devisa ini didorong oleh tingkat ekspor yang baik. Perkembangan terendah terjadi pada tahun 2013 sebesar $-11,88 \%$ dan pada tahun 2008 sebesar $-9,28 \%$.

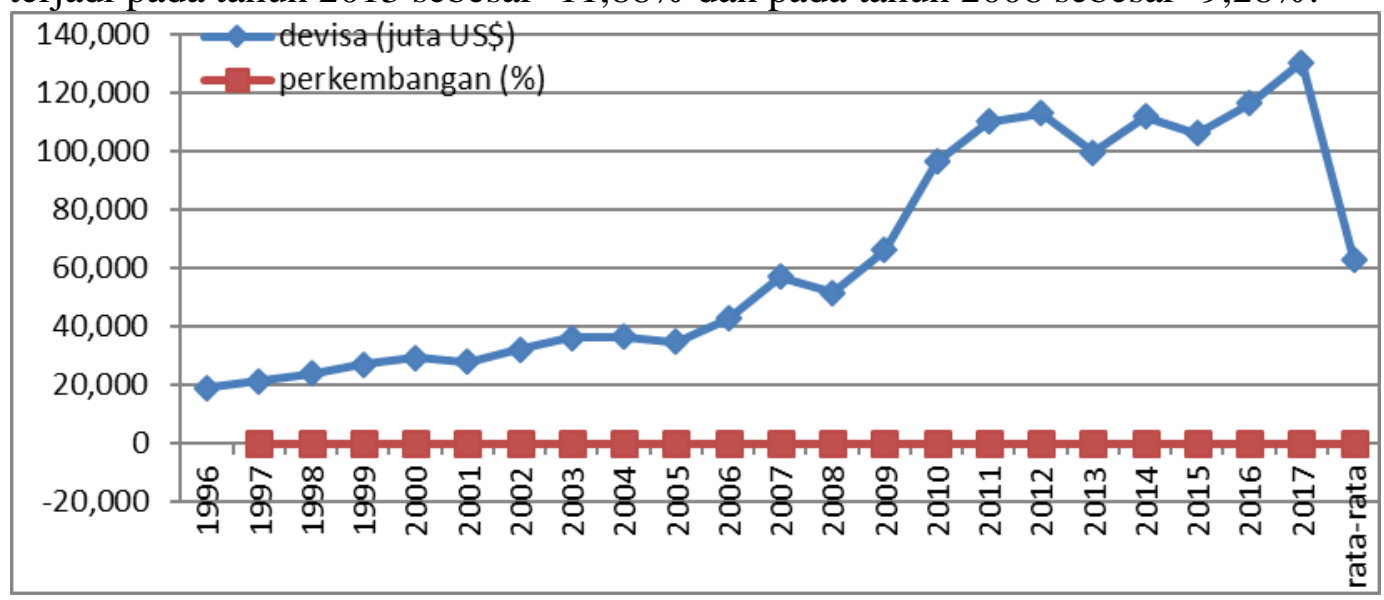

Grafik 5. Perkembangan cadangan devisa Indonesia Periode 1996-2017

Sumber: Data diolah, 2017 
Hal ini dikarenakan tingginya kebutuhan pada valuta asing untuk pembayaran imporyang tidak sesuai dengan anggaran tahun sebelumnya, utang lar negeri yang masih dimiliki oleh Indonesia dan menurunnya volume ekspor Indonesia. Keterbatasan cadangan devisa akan mempersulit untuk melakukan impor karena harus menganggarkan ulang, membatasi akan konsumsi barang maupun jasa dari luar negeri. Rata-rata perkembangan cadangan devisa Indonesia adalah $11,83 \%$ setiap tahunnya. Dapat dilihat dari grafik 5 yang menunjukkan perkembangan cadangan devisa Indonesia.

Hal ini dikarenakan tingginya kebutuhan pada valuta asing untuk pembayaran imporyang tidak sesuai dengan anggaran tahun sebelumnya, utang lar negeri yang masih dimiliki oleh Indonesia dan menurunnya volume ekspor Indonesia. Keterbatasan cadangan devisa akan mempersulit untuk melakukan impor karena harus menganggarkan ulang, membatasi akan konsumsi barang maupun jasa dari luar negeri. Rata-rata perkembangan cadangan devisa Indonesia adalah $11,83 \%$ setiap tahunnya. Dapat dilihat dari grafik 5 yang menunjukkan perkembangan cadangan devisa Indonesia.

Berdasarkan Tabel 1 diperoleh hasil estimasi model persamaan regresi linier berganda sebagai berikut:

$\log (M)=\beta 0+\beta 1 I N F+\log (\beta 2 K U R S)+\log (\beta 3 P M A)+\log (\beta 4 D E V)+e t$ $\log (M)=1,283990+0,161852$ INF $-\log (0,591907$ KURS $)+\log (0,016188$ PMA $)+\log (1,365557$ DEV $)+e_{t}$

Persamaan regresi linear tersebut dapat diinterprestasikan pada Tabel 1.

Tabel 1: Hasil regresi linear berganda

\begin{tabular}{crrrr}
\hline Variable & Coefficient & \multicolumn{1}{c}{ Std. Error } & \multicolumn{1}{c}{ t-statistic } & \multicolumn{1}{c}{ Prob. } \\
\hline C & 1.283990 & 1.805494 & 0.711157 & 0.4866 \\
INF & 0.161852 & 0.082670 & 1.957806 & 0.0669 \\
LOG(KURS) & -0.591907 & 0.226567 & -2.612507 & 0.0182 \\
LOG(PMA) & 0.016188 & 0.131658 & 0.122954 & 0.9036 \\
LOG(DEV) & 1.365557 & 0.161166 & 8.472969 & 0.0000 \\
R-squared & 0.911908 & & & \\
Adjust R-squared & 0.891180 & & & \\
F-statistic & 43.99493 & & & \\
Prob(F-statistic) & 0.000000 & & & \\
Durbin-Watson stat & 1.640719 & & &
\end{tabular}

Sumber: Data diolah, 2018

Nilai konstanta

Konstanta sebesar 1,283990 memberikan arti bahwa, jika inflasi (INF), nilai tukar (KURS), penanaman modal asing (PMA) dan cadangan devisa (DEV) diasumsikan tetap atau konstan, maka impor (M) akan naik sebesar 1,284 persen.

\section{Inflasi}

Variabel inflasi mempunyai koefisien regresi sebesar 0,161852 memberikan arti bahwa inflasi berpengaruh positif terhadap impor Indonesia dan besar probabilita 0,0669 signifikan pada $\alpha=10 \%$. Hal ini menunjukkan bahwa setiap kenaikan $1 \%$ inflasi akan terjadi kenaikan impor sebesar $0,161852 \%$ dengan asumsi variabel lainnya tetap atau konstan (ceteris paribus). 
Hasil ini sejalan dengan penelitian sebelumnya yang dilakukan (Putra, 2016), yang mengatakan bahwa inflasi berpengaruh positif dan signifikan terhadap impor. Hal ini dikarenakan semakin tinggi tingkat inflasi yang menandakan naiknya harga barangbarang dan terus menerus, sehingga impor akan meningkat dengan harga barang impor yang lebih rendah dibandingkan dengan barang dalam negeri. Hasil ini juga sejalan dengan penelitian (Ulke, 2011) dalam Econometric Analysis of Import and Inflation Relationship in Turkey Between 1995 and 2010 yang menyatakan bahwa inflasi mempunyai hubungan yang searah terhadap volume impor.

\section{Kurs (nilai tukar)}

Variabel kurs mempunyai koefisien sebesar -0,591907 memberikan arti bahwa kurs berpengaruh negatif terhadap impor Indonesia dan besar probabilita 0,0182 signifikan pada $\alpha=10 \%$. Hal ini menunjukkan bahwa setiap penambahan $1 \%$ terhadap dollar akan terjadi penurunan impor sebesar 0,591907\% dengan asumsi variabel lainnya tetap atau konstan (ceteris paribus).

Nilai impor dipengaruhi oleh kurs karena didalam melakukan perdagangan internasional tiap negara menggunakan mata uang yang berbeda maka kurs bertindak sebgai fasilitator untuk membandingkan nilai mata uang antar negara. Impor negara Indonesia turun, dipengaruhi oleh perkembangan perdagangan ketika kurs tinggi (Suryandanu, 2014). Dari penelitian ini diketahui bahwa kurs berpengaruh negatif dan signifikan terhadap impor sesuai dengan penelitian sebelumnya yang telah dilakukan oleh (Syarifah, 2007) menyimpulkan bahwa nilai tukar rupiah berkorelasi negatif dan signifikan terhadap impor, artinya semakin menguatnya nilai tukar dollar terhadap rupiah yang dipakai sebagai alat pembayaran internasional maka harga barang-barang tersebut akan semakin meningkat mengikuti nilai kurs pada saat itu.

\section{PMA (Penanaman Modal Asing)}

Variabel penanaman modal asing mempunyai koefisien regresi sebesar 0,016188 memberikan arti bahwa penanaman modal asing berpengaruh positif terhadap impor Indonesia dan besar probabilita 0,9036 tidak signifikan pada $\alpha=10 \%$. Menurut (Pacheco-Lopez, 2005) yang menyatakan terdapatnya hubungan dua arah antara impor dan pananaman modal asing. Adanya permintaan impor dari suatu negara menunjukkan adanya pasar yang menjanjikan untuk produk impor tersebut, sehingga investor akan tertarik untuk menanamkan modalnya dan melakukan proses produksi maka mereka akan melakukan impor. Dari penelitian ini diketahui bahwa penanaman modal asing tidak berpengaruh signifikan dan positif terhadap impor hal ini dikarenkan pengaruhnya tidak terlalu besar. Penanaman modal asing hanya memberikan kontribusi yang kecil terhadap kinerja impor Indonesia artinya nilai penanaman modal asing yang masuk ke Indonesia tidak begitu mempengaruhi besarnya nilai impor Indonesia. Hal tersebut mengindikasikan bahwa kinerja impor Indonesia cenderung dipengaruhi oleh faktorfaktor lain seperti inflasi, nilai tukar, cadangan devisa, pertumbuhan ekonomi dll. Hasil penelitan ini sejalan dengan hasil penelitian (Tehseen dan Jawaid, 2010) yang menyatakan bahwa penanaman modal asing tidak berpengaruh terhadap impor Taiwan yang berasal dari negara asal investor (home country).

\section{DEV (Cadangan devisa)}

Variabel cadangan mempunyai koefisien regresi sebesar 1,365557 memberikan arti bahwa cadangan devisa berpengaruh positif terhadap impor Indonesia dan besar probabilita 0,0000 signifikan pada $\alpha=10 \%$. Hal ini menunjukkan bahwa setiap naiknya 
$1 \%$ cadangan devisa akan terjadi kenaikan pada impor sebesar $1,365557 \%$ dengan asumsi variabel lainnya tetap atau konstan (ceteris paribus).

Menurut (Sultan, 2011) antara cadangan devisa dengan impor memiliki hubungan yang positif, apabila suatu negara memiliki cadangan devisa yang besar, maka kecenderungan untuk melakukan impor dari negara lain juga akan meningkat, ditambah lagi dengan beberapa kendala yang dimiliki suatu negara sehingga memutuskan untuk melakukan impor.Dari penelitian ini diketahui bahwa cadangan devisa berpengaruh positif dan signifikan terhadap impor Indonesia sesuai dengan penelitian sebelumnya yang dilakukan (Meilani, 2018) yang mengatakan bahwa cadangan devisa berpengaruh positif dan signifikan terhadap barang impor barang modal di Indonesia.

\section{Pengujian hipotesis}

\section{Uji F-statistik}

Bahwa nilai Probabilitas F hitung $(0,000000)<\alpha(0,1)$. Maka $\mathrm{H}_{\mathrm{o}}$ ditolak dan $\mathrm{H}_{\mathrm{a}}$ diterima. Jadi dapat disimpulkan bahwa impor secara bersama-sama berpengaruh terhadap inflasi, kurs, PMA dan cadangan devisa Indonesia.

\section{Uji parsial (Uji t)}

Hasil setiap variabel bebas terhadap variabel terikat secara parsial secara rinci sebagai berikut: variabel INF (inflasi) dapat dilihat bahawa nilai $\mathrm{t}$ hitung sebesar 1,957806 dengan probabilitas variabel INF (inflasi) sebesar 0,0669 atau lebih kecil dari nilai $\alpha=10 \%(0,0669<0,1)$ maka $\mathrm{H}_{0}$ ditolak dan $\mathrm{H}_{\mathrm{a}}$ diterima dan t-statistik bernilai positif. Hal ini menunjukkan bahwa inflasi berpengaruh positif dan signifikan terhadap impor Indonesia.

Variabel kurs dapat dilihat nilai t hitung sebesar $-2,612507$ dengan probabilita variabel kurs sebesar 0,0182 atau lebih kecil dari nilai $\alpha=0,1(0,0182<0,1)$ maka $\mathrm{H}_{0}$ ditolak dan $\mathrm{H}_{\mathrm{a}}$ diterima dan t-statistik bernilai negatif. Hal ini menunjukkan bahwa kurs berpengaruh negatif dan signifikan terhadap impor Indonesia.

Variabel PMA (Penanaman Modal Asing) dapat dilihat nilai t hitung sebesar 0,122954 dengan probabilita sebesar 0,9036 lebih besar dari nilai $\alpha=10 \%(0,9036>$ 0,1) maka $\mathrm{H}_{0}$ diterima dan $\mathrm{H}_{\mathrm{a}}$ ditolak dan t-statistik bernilai positif. Hal ini menunjukkan bahwa PMA berpengaruh positif dan tidak signifikan terhadap impor Indonesia.

Variabel DEV (cadangan devisa) dapat dilihat t hitung sebesar 8,472969 dengan probabilita sebesar 0,0000 lebih kecil dari nilai $\alpha=10 \%(0,0000<0,1)$ maka $\mathrm{H}_{0}$ ditolak dan $\mathrm{H}_{\mathrm{a}}$ diterima dan t-statistik bernilai positif. Hal ini menunjukkan bahwa cadangan devisa berpengaruh positif dan signifikan terhadap impor Indonesia.

\section{Koefisien determinasi $\left(\mathbf{R}^{2}\right)$}

Pada hasil perhitungan statistic diperoleh besarnya nilai koefisien determinan $\left(\mathrm{R}^{2}\right)$ adalah 0,911908. Hal ini menunjukkan bahwa persentase pengaruh variabel bebas (inflasi, kurs, PMA dan cadangan devisa) terhadap variabel terikat (impor) adalah sebesar $91,19 \%$. Artinya inflasi, kurs, PMA dan cadangan devisa memiliki persentase pengaruh terhadap impor Indonesia sebesar 91,19\%, sedangkan sisanya $8,81 \%$ dipengaruhi oleh variabel lain yang tidak dimasukkan dalam model penelitian ini.

\section{Uji multikolinearitas}

Salah satu cara yang digunakan adanya korelasi linier antar variabel bebas dalam model empiris. Multikolinearitas dapat dilihat juga dari tolerance and variance inflation factors (VIF). 
Tabel 2. Hasil uji multikolinearitas

\begin{tabular}{cccc}
\hline Variable & Coefficient variance & Uncentered VIF & Centered VIF \\
\hline C & 3.259807 & 1229.010 & NA \\
INF & 0.006834 & 11.07299 & 1.460948 \\
LOG(KURS) & 0.051332 & 1609.483 & 2.694145 \\
LOG(PMA) & 0.017334 & 618.7711 & 1.585989 \\
LOG(DEV) & 0.025975 & 1158.623 & 3.935935 \\
\hline
\end{tabular}

Sumber: Data diolah, 2018

Hasil output dapat dilihat Centered VIF kurang dari 10, maka dapat disimpulkan bahwa tidak terjadi multikolinearitas dan hal tersebut menunjukkan adanya hubungan linear yang sempurna diantara beberapa atau semua variabel bebas dari model regresi.

\section{Uji heterokedastisitas}

Untuk menguji masalah heterokedastisitas pada model ini maka digunakan pengujian Breusch-Pagan-Godfrey. Jika terjadi heterokedastisitas maka penaksir OLS tetap tak bias atau konsisten, tetapi penaksir tadi tidak lagi efisien baik dalam sampel kecil maupun besar.

Tabel 3. Hasil uji heterokedastisitas

\begin{tabular}{llll}
\hline F-statistic & 0.710831 & Prob. F(4,17) & 0.5957 \\
Obs*R-squared & 3.152352 & Prob. Chi-Square(4) & 0.5327 \\
Scaled explained SS & 3.175290 & Prob. Chi-Square(4) & 0.5289
\end{tabular}

Sumber: Data diolah, 2018

Dari hasil output dapat dilihat Chi-Square hitung sebesar 3,152352 yang dapat dilihat dari Obs*R-squared. Sementara dapat dilihat nilai prob. Chi-Square dari model ini adalah 0,5327 atau 53,27\%, yang menunjukan bahwa nilai tersebut lebih besar dari nilai kritis Chi-Squared $\left(\mathrm{x}^{2}\right)$ yaitu sebesar 0,05 atau $5 \%$. Maka dapat disimpulkan bahwa tidak memiliki sifat heterokedastisitas.

\section{Uji autokorelasi}

Autokorelasi adalah yang terjadi dalam satu variabel. Korelasi ini terjadi antar waktu atau individu. Umumnya kasus autokorelasi banyak terjadi pada data time series, artinya kondisi sekarang dipengaruhi waktu yang lalu.

Tabel 4. Hasil autokorelasi Breusch-Godfrey Serial Correlation LM test

\begin{tabular}{llll}
\hline F-statistic & 0.762563 & Prob. F(2,15) & 0.4837 \\
Obs*R-squared & 2.030409 & Prob. Chi-Square(2) & 0.3623
\end{tabular}

Sumber: Data diolah, 2019

Hasil output dapat dilihat model regresi tidak terjadi autokorelasi. Hal ini dapat dilihat dari nilai Prob. Chi-Square sebesar 0,3623 atau 36,23\% lebih besar dari nilai $\alpha=$ $5 \%(0,05)$. Maka dapat disimpulkan bahwa tidak terjadi hubungan linear dalam model yang digunakan. 


\section{Uji normalitas}

Uji yang dilakukan untuk mengevaluasi apakah nilai variabel pengganggu dari model yang dibentuk sudah normal atau tidak. Konsep pengujian uji normalitas menggunakan pendekatan Jorque-Berra test.
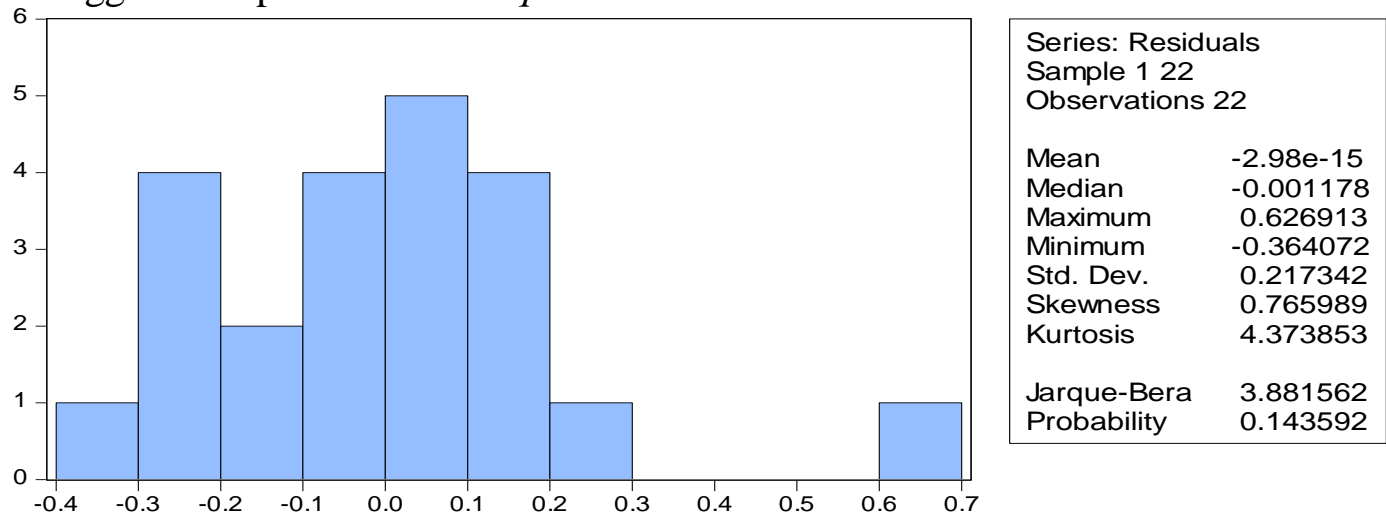

Gambar.1. Uji normalitas

Dapat dilihat hasil output nilai probabilita J-B hitung adalah 0,143592 atau $14,36 \%$ lebih besar dari nilai $\alpha=5 \%(0,05)$ maka dapat disimpulkan bahwa model ini lolos dari ketidaknormalan atau data berdistribusi normal.

\section{Implikasi kebijakan hasil penelitian}

Berdasarkan hasil pengujian statistik yang telah dilakukan maka dapat disimpulkan bagaimana pengaruh variabel inflasi, kurs, PMA dan cadangan devisa terhadap impor Indonesia periode 1996-2017. Inflasi memiliki pengaruh yang signifikan terhadap impor Indonesia, ini terjadi karena naik atau turunnya inflasi akan berpengaruh terhadap nilai impor Indonesia sehingga hubungan antar variabel menjadi positif. Dan cadangan devisa memiliki pengaruh yang signifikan terhadap impor Indonesia, ini terjadi karena naik turunnya nilai cadangan devisa akan berpengaruh terhadap nilai impor Indonesia sehingga hubungan antar variabel menjadi positif.

Hasil dari penelitian diatas, maka peneliti mengemukakan beberapa pendapat yang perlu diperhatikan dalam menentukan kebijakan yang berkaitan dengan menjaga kestabilan tingkat inflasi, kestabilan nilai tukar, peningkatan PMA dan peningkatan cadangan devisa agar nilai impor Indonesia lebih stabil dan tidak lebih besar dari nilai ekspor Indonesia. Kebijakan untuk menurunkan nilai impor Indonesia pemerintah harus menjaga kestabilan inflasi karena inflasi yang meningkat akan meningkatkan nilai impor Indonesia. Peningkatan inflasi jika diikuti dengan depresiasi kurs dan peningkatan cadangan devisa, dengan terjadinya variabel tersebut akan menjadikan nilai impor menjadi meningkat tinggi yang akan menyebabkan defisit. Pemerintah harus dapat menjaga kestabilan inflasi, diikuti dengan terapresiasinya kurs akan menjadikan surplus, nilai impor di tekan lebih rendah dibandingkan impor ditahun-tahun berikutnya.

\section{KESIMPULAN DAN SARAN}

\section{Kesimpulan}

Berdasarkan hasil uraian pada hasil penelitian, maka dapat diambil kesimpulan sebagai berikut: Rata-rata perkembangan impor sebesar $8,68 \%$ pertahun, rata-rata perkembangan inflasi sebesar 56,86\% pertahun, rata-rata perkembangan nilai tukar rupiah terhadap dollar sebesar $11,17 \%$ pertahun, rata-rata perkembangan PMA sebesar $10,30 \%$ pertahun, dan rata-rata perkembangan cadangan devisa sebesar $11,83 \%$ pertahun. Dan dari hasil regresi variabel inflasi, kurs dan cadangan devisa berpengaruh dan signifikan terhadap impor Indonesia. 


\section{Saran}

Menjaga kestabilan inflasi agar tidak terjadinya kenaikan inflasi yang ekstrim yang menyebabkan harga-harga dalam negeri lebih mahal dari luar negeri sehingga impor Indonesia dapat di minimalisir setiap tahunnya. Dan menjaga kestabilan kurs sehingga impor di Indonesia juga dapat stabil. Dan diharapkan kepada pemerintah harus mendorong para pengusaha untuk menaikkan hasil produksinya, kemudian pemerintah melakukan pengawasan harga dan sekaligus menetapkan harga maksimal. Untuk menambah cadangan devisa, pemerintah sebaliknya mencari sumber-sumber yang memang akan menguntungkan, salah satunya keuntungan dari hasil perdagangan luar negeri dan meminimalisir hal-hal yang akan mengurangi cadangan devisa seperti impor yang masuk ke Indonesia.

\section{DAFTAR PUSTAKA}

Amir, Amri. (2000). Pengaruh inflasi dan pertumbuhan ekonomi terhadap pengangguran di Indonesia, Jurnal Inflasi dan Pengangguran, 1(1). 4-9

Emilia,E; \& R Nurjanah. (2015). Analisis pengaruh ekspor ke china terhadap pendapatan perkapita dan penyerapan tenaga kerja di indonesia, Jurnal Paradigma Ekonomika 10 (2)

Juniantara, I.P.K; \& Sri Budhi, M.K. (2012). Pengaruh ekspor impor dan kurs terhadap cadangan devisa nasional periode 1990-2010, Jurnal Ekonomi Pembangunan Universitas Udayana, 1(1). 1-60

Meilani, Refti. (2018). Analisis pengaruh kurs dollar Amerika, inflasi, cadangan devisa dan PDB terhadap impor barang modal di Indonesia tahun 1987-2016. Skripsi. Fakultas Ekonomi dan Bisnis, Universitas Muhammadiyah Surakarta: Surakarta.

Pacheco-Lopèz, P. (2005) Foreign direct investment, exports and imports in Mexico. Department of Economics University of Kent: Mexico.

Putra, Thariq Perdana. (2016). Analisis pengaruh inflasi, kurs, PDB, cadangan devisa dan PMA terhadap nilai impor di Indonesia 2009-2015. Skripsi. Fakultas Ekonomi dan Bisnis, Universitas Lampung: Lampung.

Rosita,R; H Haryadi;\& A Amril. (2015). Determinan ekspor CPO Indonesia, Jurnal Perspektif Pembiayaan dan Pembangunan Daerah, 1 (4), 183-183

Sukirno, Sadono. (2015). Makro ekonomi teori pengantar. PT. Raja Grafindo Persada: Jakarta.

Sultan, Zafar Ahmad. (2011). Foreign exchange reserves and India's imports demand: a cointegration and vector error correction analysis, International Journal of Bussiness and Management. 5(6), 69-76

Suryandanu, dkk. (2012). Faktor-faktor yang berpengaruh terhadap impor barang konsumsi di Indonesia, E-jurnal EP UNUD, 3(12). 549-623

Syarifah; \& Idgan. (2017). Faktor-faktor yang mempengaruhi impor susu Indonesia, Jurnal Manajemen dan Agribisnis, 4(2). 91-102.

Ulke, Volkan; \& Urgun Ergun. (2011). Econometric analysis of import and inflation relationship in Turkey between 1995-2010, Journal of Economic and Social Studies. 1(2), 69-84

Waheed, A.S. Tehseen; \& Jawaid. (2010). Inward foreign direct investment and aggregate imports. Time series evidence from Pakistan, International Economics and Finance Journal, 5(1), 1-2. 